кандидат філологічних наук, дочент

КПІ ДВНЗ «Криворізький наиіональний університет»

Журба $О$.

учитель української мови та літератури КСШ № 107

\title{
АВТОБІОГРАФІЧНІСТЬ РОМАНУ «МАЙСТЕР КОРАБЛЯ» Ю. ЯНОВСЬКОГО
}

Статтю присвячено дослідженню автобіографічності та автотематичності роману Ю. Яновського «Майстер корабля» з метою глибше розкрити специфіку художньої майстерності мития $і$ висвітлення прочесу творчості як засобу самовираження письменника.

Ключові слова: автобіографічність, прототип, прочес творчості, митеиь, мистецтво.

Статья посвящена исследованию автобиографичности и автотематичности романа Ю. Яновского «Мастер корабля» с челью глубже раскрыть специфику художественного мастерства писателя и освещения прочесса творчества как средства самовыражения автора.

Ключевые слова: автобиографичность, прототип, прочесс творчества, художник, искусство.

The article investigates autobiographical and autothematical novel "The Master of the ship". Biographical facts allow deeper to reveal specific artistic skill of the artist, presenting the creative process as a means of self-expression writer.

Keywords: autobiographical, prototype, process art, artist, art.

«Майстер корабля» - один із найоригінальніших романів доби українського "розстріляного відродження», який, на думку літературознавця Тетяни Ткаченко, визначається як «багаторівневий полісемантичний твір, у якому переплітаються кілька аспектів, а саме: автобіографічна нарація (Одеська кіностудія, ТоМа-Кі - прототип Ю. Яновський), суспільно-історичний контекст (псевдоукраїнізація та іiі наслідки), літературний інтертекст (М. Гоголь, Дж. Конрад і Дж. Пассос) та біблійна символіка, що набуває нової інтерпретації в літературному тексті». Крім того, твір є «своєрідною мозаїкою, де поєднано розмаїття жанрів (ме- 
муари, белетристика, притча, епістолярій, саморефлексії персонажів), які утворюють художню формозмістову цілісність» [Ткаченко 2010: 395]. Сучасна дослідниця творчості Ю. Яновського Мирослава Гнатюк вказує, що роман став новою віхою в художній еволюції митця, а вираження «його творчої волі запоручувала смілива одвертість, яка логічно вмотивовувала текст, надаючи завершальності глибоким роздумам про мову і культуру, державу й особистість, сучасне та майбутнє, духовно-моральні орієнтири нації» [Гнатюк 2006: 19].

Творчість цього талановитого митця стала об'єктом вивчення багатьох науковців, зокрема літературні експерименти Юрія Яновського не тільки не залишилися поза увагою його сучасників (О. Білецький, В. Підмогильний, Гр. Майфет, А. Ніковський, Л. Старинкевич та ін.), але й досі перебувають у центрі уваги багатьох критиків. Так, останнім часом з'явилася чимала кількість наукових розвідок, присвячених «секретам поетичної творчості» Ю. Яновського. Це, передовсім, дослідження В. Агєєвої, М. Гнатюк, Я. Голобородька, Л. Кавун， Н. Коробкової， М. Ласло-Куцюк， Р. Мовчан， М. Наснка, В. Панченка, І. Семенчука, Т. Ткаченко, Р. Харчук та інших. У своїх дослідженнях літературознавці глибоко проаналізували творчість письменника, особлива увага зверталась на тематику, проблематику й ідейний зміст творів, композицію, жанрову специфіку, міфологізм, поетику образів. Біографічна автореференційність Юрія Яновського як своєрідне самооповіщення, вказівка на самого себе, де автор і його поетика стають предметом власного тексту, $є$ предметом дослідження М. Гнатюк [Гнатюк 2006]. Проте питання автобіографічності та автотематичності в романі залишається невичерпним, саме цим і зумовлена актуальність нашого дослідження.

Оскільки біографії ставали домінантами творчості багатьох українських митців (Тараса Шевченка, Івана Франка, Володимира Сосюри, Олександра Довженка, Івана Багряного й інших), саме ці митці ставали прототипами або й героями своїх творів. Ю. Яновський в автобіографії зазначав, що біографія у нього надто коротка 
і вражаючих фактів у ній нібито немає. Проте період роботи на Одеській кінофабриці був насичений подіями, які знайшли своє втілення в романі «Майстер корабля», вважала дружина письменника Тамара Яновська: «Глибокий слід у творчості Яновського залишила його прачя у кінематографії, де він якийсь час прауював редактором. Цей період його життя знайшов відображення в романі "Майстер корабля" та в книжиі "Голлівуд на березі Чорного моря", виданій 1930 року» [Лист у вічність 1980: 80-81]. Письменник у романі осмислив власний життєвий досвід, пов'язаний із роботою на Одеській кіностудії. Прозаїк є прототипом головного героя - оповідача То-Ма-Кі - знаного і заслуженого кінорежисера. Ю. Яновський, використавши форму мемуарів, художньо осмислив тогочасне мистецьке життя, зокрема розвиток кіноіндустрії, а також в образах Сева, Професора, Директора, Богдана зобразив своїх друзів по цеху та відтворив атмосферу, що спонукала молоду генерацію до осягнення нових творчих звершень, будівництва нового суспільства за законами краси й гармонії.

Герої роману - це такі «твориі молодої Республіки й української кінематографії, за химерними іменами яких були прототипи реальних людей, представників творчої інтелігенції» [Гнатюк 2006: 19] - Олександра Довженка, Павла Нечеси, Василя Кричевського, Іти Пензо, з якими співпрацював і дружив Ю. Яновський, вважає дослідниця Мирослава Гнатюк. У творі наратор «переодягає) їх у романтичних, сповнених сил і натхнення персонажів Сева, Професора, балерину Тайах, Директора. Письменник, на думку Р. Мовчан, «насичуючи "Майстра корабля" авантюрними, пригоднищькими елементами, натхненно передаючи життєствердну атмосферу творчості, дерзання, намагаючись "увіковічити" в образах романтичних героїв своє вишукане, рідне по духу товариство (О. Довженко, В. Кричевський, П. Нечеса, Іта Пензо, Г. Гричер), сміливо дав волю своїй розкішній уяві» [Мовчан 1999: 7].

Молодим і сповненим сил на посаді художнього редактора кінофабрики з'явився в 1926 році сам Ю. Яновський. «До кінофаб- 
рики я приїхав молодий і простий, як солдат з булавою маршала в раниіi» [Яновський 1983: 13], - зізнається у своїх мемуарах То-Ма-Кі. До Одеси молодого письменника «перетяг» відомий футурист Михайль Семенко. Останній «витратив не багато аргументів, щоб переконати тебе (Яновського) приєднатися до його футуристичної кумпанії, почати прачю в редакції, друкуватися в газеті» [Бажан 1982: 11], а також запропонував писати сценарії до кінофільмів, і молодий письменник почав працювати «під егідою Михайля Семенка у Всеукраӥнському фото-кіноуправлінні〉, у якому відомий лідер футуристів «завідував сценарною редакиією», а «Юра був унього редактором» [Бажан 1982: 18], - згадує Микола Бажан. Юрій Яновський дружив не тільки з Олександром Довженком, але й з Миколою Бажаном, Михайлем Семенком. Нова галузь мистецтва - кіноіндустрія - потребувала нових сил, якими стали молоді письменники Майк Йогансен, О. Досвітній, Д. Бузько, Ю. Яновський та М. Бажан. Останні вперше почули «шелестіння кіноапарата та тріщання юпітерів» [Бажан 1982: 19], і ці перші «намі кроки в кіно були спробами дитини, що вчиться ходити» [Яновський 1983: 8]. 3 Йогансеном, Слісаренком, Смоличем, Довженком у 20-х Юрій Яновський входив до ВАПЛІТЕ, і з останнім разом довелося працювати пліч-опліч на Одеській кіностудії. У цей час робив свої перші спроби радянський кінематограф, біля керма якого стояв визначний майстер кіно Олександр Довженко, і першими досягненнями його стали «Арсенал», динамічна «Сумка дипкур'єра», іронічно-символічна «Звенигора». У 20-х Одеса захворіла на кіноманію і величала себе «Голлівудом на березі Чорного моря». Творчі й життєві шляхи Юрія Яновського та Олександра Довженка перетнулись саме тут, що вилилось у спільну творчість і міцну дружбу. У «Майстрі корабля» То-Ма-Кі (автор) називає Сева (Довженка) - «мій перший друг. Прийшовии режисером у кіно, він поставив невеличку комедію й блискуче провалився. За че він дозволив собі відпустку на кілька місячів. Тепер він знову повернувся до Міста й буде ставити ще одну картину» [Яновський 1983: 35]. Перший фільм О. Дов- 
женка «Вася-реформатор» був невдало «зафільмований» і надалі став недоступним для широкого глядача, натомість комедія «Ягодка кохання» принесла йому успіх. Молодий кінорежисер став духовно близьким Юрію Яновському, для якого завжди був талановитим майстром і вірним другом.

Прототипами героїв роману «Майстер корабля» Ю. Яновського були й працівники Одеської кіностудії 20-х років. Зокрема, Василь Кричевський, художник, який був запрошений як консультант фільмів на історичні теми, у романі став мудрим всезнаючим Професором. У спогадах М. Бажана читаємо: «Старий майстер знав багато. Свойми знаннями він не хизувався, а охоче ділився, ставши незаперечним художнім авторитетом для всіх кінематографістів, особливо ж для двох людей - для Довженка, загалом не схильного підкорятися у мистечтві іншим авторитетам, $i$ для Яновського. Юрій дуже любив і шанував свого Професора, прислухався до його суджень, учився у нього» [Бажан 1982: 27]. Обкладинку до першого видання «Майстра корабля» виконав саме В. Кричевський. На ній було зображено вітрильник, який ніби летить над морем, нагадуючи своїми контурами жіноче обличчя східного типу - героїні твору балерини Тайах (це ім'я запозичене 3 історії стародавнього Сгипту. Так звали матір фараона Ехнатона, свекруху знаменитої Ніфертіті). Прототипом Тайах була артистка Іта Пензо, яка гастролювала у 20-ті роки в Одеському оперному театрі і танцювала в балеті С. Василенка «Йосиф Прекрасний».

«Майстер корабля» вирізняється у творчому доробку Ю. Яновського, «з одного боку, зосередженістю на мистеџькій проблематичі, а з іншого, максимальною увагою до самого творчого прочесу», як зауважує Віра Агеєва [Агеєва 2002: 304]. Письменник зосередив увагу на мистецтві, пов'язаному з технікою, ремеслом кіно. Складним ремеслом і високим мистецтвом представлене у творі й кораблебудування. Вміння цінувати «досконалість рукотворної праці» (М. Бажан) було притаманне Ю. Яновському, який у романі проспівав гімн рукам та витворам їх рукотворної краси. 
Тема митця та мистецтва, його «сутності й перспектив» (Я. Голобородько) розгортається у «Майстрі корабля» в кількох аспектах. Найперше ії репрезентують герої - То-Ма-Кі й Сев, тісно пов'язані з кіновиробництвом, син То-Ма-Кі - письменник Генрі та балерина Тайах. Ці неординарні творчі особистості висловлюють своє розуміння мистецтва, і з багатоголосся їхніх міркувань викристалізовується думка про те, що мистецтво окрилює людину, у творчості людина здобуває безсмертя.

Кіномайстер То-Ма-Кі, що від його особи ведеться оповідь роману, усе своє життя присвятив великій справі творення нової культури нації, одного із «тих багатьох мікрокосмів, енергією яких заряджається, запускається макрокосм - людство - світова культура», вказує літературознавець Лідія Кавун [Кавун 2009: 368]. «Сімдесят років стою я на землі, пройшли переді мною покоління чужих $i$ рідних людей, і всім я з гордістю дивився в вічі, боронячи життя й честь моєї нареченої. Ї̈ коси, як струмені, розлились по землі, ї руки, як благословення, лягли на поля, ї серце палає, як серце землі, посилаючи жагучу кров на нові й нові шляхи. Для неї я був сміливий і впертий, заради неї я хотів бути в першій лаві бійців - бійців за ї розквітання. Для неї я полюбив море, поставив на гербі якір, залізний важкий якір, що його приймають усі моря світу, $і$ колишеться над ним могутній корабель. Культура нації - звуть ї̈» [Яновський 1983: 29-30]. Серед них особливо вирізнялася проблема культури української нації, як одна 3 найважливіших соціально-етичних проблем. В останніх словах утілено романтичну ілюзію ще не розчарованої та не розчавленої тоталітарним режимом української інтелігенції 1920-х рр. «Свобода думки й творчості, - вважає сучасна дослідниия Мирослава Гнатюк, - асоціюється у творі $з$ радістю відчуття безмежного простору, з гордістю за свою наречену - "культуру наиії", якій То-Ма-Кі складає пристрасну клятву. Культура як гарант незнищенності народу та людини, запоручені ій власним життям - основні складові "Майстра корабля". Потужність духовного й культурного потенціалу начії співвідне- 
сено автором з найважливішою домінантою - радісною праџею, щчо є ознакою творчості» [Гнатюк 2006: 20].

Ю. Яновський акцентує красу творчої праці, що втілюється в образах Сева, Редактора, Богдана, Професора, Тайах (з допомогою цих героїв розширюються просторові межі роману), людей, які будують прекрасний Корабель - культуру нації. Мотив, «пов'язаний із "культурою", охоплює кілька значень. Це й певна історико-культурна доба, і натхнення, і творча еволючія, $і$ творчість, як така, $і$ мистеитво загалом», - зазначає дослідниця Лідія Кавун [Кавун 2009: 369].

Сутність мистецтва, на думку героїв, полягає в поєднанні романтичної глибинності, натуралістичної виразності, образної аналітичності, реалістичної конкретності, епічної метафоричності, символічності мислення. У спогадах «Голлівуд на березі Чорного моря» Юрій Яновський згадує розмову з Довженком, який «сяде на n'яти ніг, як Будда, i, викладає своє розуміння мистечтва» [Яновський 2002: 236]. Прагнення Олександра Довженка до «живого пересування картин малюнка, сюжетного пов'язання емоцій і живих, теплих людей» [Яновський 2002: 236] захоплювало письменника Яновського, і він «егоїстично занотовував думки» [Яновський 2002: 236] свого колеги. І все ж молодий кінорежисер «знайшов полотно, на якому постаті й образи, покладені пензлем, рухаються, живуть, ненавидять і кохають. Його прямування довело його до правдивих шляхів і живих обріїв» [Яновський 2002: 236-237]. Важливим для розуміння своєрідності естетичного мислення письменника в романі $\epsilon$ діалог між героєм-редактором та Севом про конкретні принципи й підходи зображення моря, морського буття, що став «естетичним маніфестуванням автора» (Я. Голобородько). У цьому діалозі Сев і Редактор виступають однодумцями, які, на думку сучасного критика Я. Голобородька, «декларують необхідність відходу від шаблонів, узвичаєних схем у художньому зображенні» [Голобородько 2004: 133].

Ю. Яновський вкладав у свій перший великий твір і порив до прекрасного, і свіжість пізнання, і певну надмірність, що пояс- 
нювалась зворушливим хлопчачим запалом, який супроводжував усю творчість митця. Степ і море - саме до них прагнув письменник, виходячи із задимлених кабінетів кінофабрики. Юрій Яновський був дитиною степу, але його давнім захопленням, пристрастю було море, і це знайшло своє втілення в романі: «Ми розмовляли про ніжні пахощі степів, які може відуути лише чутливий ніс тубільця. Безконечний, родючий степ поріс травою й поховав дороги. Як у морі, хвилюється його зелена поверхня, багато фарб розкидано по cтепу, щеедрих, щирих фарб збудженої землі. I високе бліде небо блакитними шовками звисає до обріїв, дзвенить відблисками дорогого каміння, голубими переливами степової тайни й високими, наче з безвісти донесеними, мелодіями степових птахів, щуо приліпилися десь у небі й ніяк не знайти їх простим оком. Пливе степ, наставивии вітрила. Море - пустельний степ одного обарвлення й одного запаху. Через цуе людина шукає інших морів, дальших обрії $і$ солодиої тайни. Степ межує з морем, щзо завще приймало на свої вітри журавлів із степу» [Яновський 1983: 48]. Ці дві іпостасі стильової палітри настільки переплелися, що романтикою моря у творі насичена кожна фраза, образ і тропи. У творі морським повітрям, завзяттям, творчим захопленням, екстазом наповнене все, і здається, що море шумить на сторінках роману. Романтикою моря зачаровував мрійливу душу молодого письменника Джозеф Конрад, із творів якого український митець почерпнув деякі факти 3 життя моряків, залюбленість у море, неоромантичний пафос.

Саме $з$ морем пов' язаний новий фільм, який готується знімати Сев («Сценарій морський думаю... Море, корабель, наші матроси й нудьга за батьківщиною» [Яновський 1983: 39]) і для якого будують корабель. У 1922 році газета «Пролетарская правда» надрукувала вірш «Море», автором якого був Георгій Ней. Саме під таким вишуканим псевдонімом ховався Юрій Яновський, який навчався на електромеханічному факультеті Київського політеху і мріяв будувати кораблі. Михайль Семенко, прочитавши цю романтичну оду відважному екіпажеві корабля, зацікавився постаттю автора. Саме $\mathrm{Ce}$ - 
менко «спокусив» і перетягнув до Харкова для роботи у Всеукраїнському фото-кіноуправлінні (ВУФКУ) молодого письменника.

Отже, «Майстер корабля» - український модерністичний роман нового типу, про що постійно наголошував Ю. Яновський. Герої роману є пристрасними натурами, які прагнуть до нових висот творчої праці, вносять дух неспокою, оптимізму, пориваються, як і автор твору, до нових творчих звершень. А біографічні алюзії, художньо осмислені наратором, у творі підкреслюють романтичність образів, збагачують його художню картину, надаючи їй екзотичності, життєствердності. Романтичні персонажі твору, як і їх прототипи - О. Довженко, Ю. Яновський, Іта Пензо, П. Нечеса, В. Кричевський, сповнені сил, наснаги, творці нового мистецтва, прагнуть відродити духовність української нації. Тому роман «Майстер корабля» засвідчив не тільки «апофеоз духовного зросту неоромантика Юрія Яновського» [Мовчан 1999: 7], а й визначив морально-етичну наповненість українця, його духовну основу, відчуття себе частинкою нації, що творила нове життя.

\section{БІБЛІОГРАФІЯ}

Агеєва 2002 - Агеєва В. Романний експеримент Юрія Яновського / Віра Агеєва // Патетичний фрегат: Роман Юрія Яновського «Майстер корабля» як літературна містифікація / упоряд. В. Панченко. - К. : Факт, 2002. - С. 301-310.

Бажан 1982 - Бажан М. П. Думи і спогади / М. П. Бажан. - К. : Радянський письменник, 1982. - $326 \mathrm{c}$.

Гнатюк 2006 - Гнатюк М. М. Текстологічні проблеми творчості Юрія Яновського: теоретичний аспект : автореф. дис. ... д-ра філол. наук : 10.01 .06 - теорія літератури ; 10.01.01 - українська література / Мирослава Михайлівна Гнатюк. -К., 2006. - 41 с.

Голобородько 2004 - Голобородько Я. Естетична поліфонія Ю. Яновського: Романи «Майстер корабля», «Чотири шаблі», «Вершники» / Ярослав Голобородько // Українська мова та література в середніх школах, ліцеях та колегіумах. - 2004. № 4. - С. 129-142.

Кавун 2009 - Кавун Л. Художня модель ідеального світоустрою в романі Юрія Яновського «Майстер корабля» / Лідія Кавун // Актуальні проблеми слов’янської філологіі. Серія «Лінгвістика і літературознавство» : міжвуз. зб. наук. ст. / відп. ред. В. А. Зарва. - Бердянськ : БДПУ, 2009. - Вип. ХХІІ. - С. 367-375.

Лист у вічність 1980 - Лист у вічність: Спогади про Юрія Яновського. - К. : Дніпро, 1980. - 349 с.

Мовчан 1999 - Мовчан Р. «Благословіть почати щирий труд, що відчинив би далину, як двері...» (Неоромантизм ранньої прози Ю. Яновського) / Раїса Мовчан // Українська мова та література. - 1999. - Число 45. - С. 4-7. 
Панченко 2002 - Панченко В. «Книга легка і життєжадібна...» / Володимир Панченко // Патетичний фрегат: Роман Юрія Яновського «Майстер корабля» як літературна містифікація / упоряд. В. Панченко. - К. : Факт, 2002. - С. 287-300.

Патетичний фрегат 2002 - Патетичний фрегат: Роман Юрія Яновського «Майстер корабля» як літературна містифікація / [упоряд. В. Панченко]. - К. : Факт, 2002. - 344 с.

Ткаченко 2010 - Ткаченко Т. І. Роль біблійного інтертексту в романі Ю. Яновського «Майстер корабля» / Т. І. Ткаченко // Актуальні проблеми слов'янської філологіi. Серія «Лінгвістика і літературознавство» : міжвуз. зб. наук. ст. / відп. ред. В. А. Зарва. - Бердянськ : БДПУ, 2010. - Вип. ХХІІІ. - Ч. 1. - С. 395-400.

Яновський 2002 - Яновський Ю. Голлівуд на березі Чорного моря / Юрій Яновський // Патетичний фрегат: Роман Юрія Яновського «Майстер корабля» як літературна містифікація / упоряд. В. Панченко. - К. : Факт, 2002. - С. 231-248.

Яновський 1983 - Яновський Ю. І. Твори : в 5 т. / Ю. І. Яновський. - Т. 2 : романи / упоряд., прим. К. П. Волинського, М. Острика ; післям. М. Пархоменка]. - К. : Дніпро, 1983. -424 с. 